\title{
Quality of Information Disclosed in Annual Reports of Listed Companies in the Czech Republic \\ David Čevela*
}

\begin{abstract}
:
This article examines the periodic information duty of the companies listed on Prague Stock Exchange in relation to the information disclosed within annual reports. The most significant regulatory requirements in force as at December 31, 2013 are identified and divided into several sub-areas - requirements on the financial statements, Report on relations and the Report of the Board of Directors, notes and complementary information and financial position and financial results.

The identified requirements are then confronted with actual information disclosed within annual reports of the companies analysed to assess the compliance with the applicable law and IFRS. The main objective of the research is to evaluate the degree to which the listed entities comply with the reporting requirements set by the current legal framework by means of a content analysis using a predefined scoring system. The concluding section summarizes the main findings and suggests further possible research in this area.
\end{abstract}

Key words: Prague Stock Exchange; Periodic disclosure; Disclosure quality.

JEL classification: G18.

\section{Introduction}

Commercial companies are among many other rights and duties subject to an obligation to provide a specific set of relevant information, whether for the needs of its owners, or other relevant users such as potential investors, lenders and creditors, employees, customers, regulatory organs and others (Zelenka, Zelenková, 2011). It is also clear that the greatest demands on a relatively detailed information to be provided externally to all stakeholders will be imposed on companies that are issuers of shares and other securities on a stock exchange (in the Czech Republic the Prague Stock Exchange, Inc.), i.e. so-called listed companies. The goal of this paper is to assess the degree to which such entities comply with the reporting requirements set by the current legal framework. A possible non-compliance with these requirements could cause a material misguidance of stakeholders arising from incorrect, incomplete or even biased information provided by a listed company.

Ing. David Čevela; University of Economics, Prague, Faculty of Finance and Accounting, W. Churchill Sq. 4, 13067 Prague, Czech Republic; <xcevd00@vse.cz>.

The article has been prepared under Institutional support of the Faculty of Finance and Accounting, University of Economics, Prague (VŠE IP 100040). 
Čevela, D.: $\quad$ Quality of Information Disclosed in Annual Reports of Listed Companies in the Czech Republic.

\section{Literature Review}

Research in the area of compliance with either financial reporting standards or other accounting regulatory requirements in individual European Union (EU) member countries, specifically in the Czech Republic, is rather limited. Many studies cover relevant topics within the international coverage, considering mostly the more developed or larger EU markets (compared to the Czech Republic). These arose mostly with the mandatory IFRS adoption for listed companies in EU countries after 2005. Among those studies e.g. Morais \& Curto (2009) discuss the increase of value-relevance of financial information disclosed by companies and find that companies in countries with less legal enforcement disclose more relevant accounting information. Among the recent studies Glaum et al., (2013) strive to establish a framework to set the determinants of compliance with some IFRS standards analysing a pool of companies from various countries for the year 2005 (six of them are Czech companies). Authors arrive to a conclusion, that a compliance is closely linked to industry and country specific factors. A content analysis method was used by Dyczkowska (2014) who examined public disclosures made by Polish stock issuers through their web pages in 2012 and identified that only a small number of companies were presenting detailed voluntary disclosures.

A descriptive approach of research was chosen by e.g. Verriest et. al. (2013) who among other tested a disclosure quality for the first year of IFRS adoption and discovered a substantial heterogeneity of the compliance with IFRS among European countries. Daske et al. (2013) discuss difference between disclosures provided with honest desire for more transparency ("serious adopters") and only formal disclosures ("labels") and its effect on reporting quality by analysing companies' annual reports, including some Czech companies. Quality of disclosure from a different perspective is evaluated in a study of Goodwin et al. (2009) who inspected a correlation between a quality of specific disclosures and a company governance structure. Miková (2014) on a sample of 603 companies (three Czech companies were included) discusses that the reporting quality depends on the national legal system and its enforcement mechanisms.

However, currently the specific set of reporting obligations imposed on companies whose shares are traded on the Prague Stock Exchange (PSE) are mostly covered only by a specialized legal literature. Most of them are books on the Act On Capital Market Undertakings and the Commercial Code with commentary, such as Husták et al. (2012), or Švestka et al. (2008) and thus do not tackle the practical adoption and specific accounting implications. We can conclude that specific empirical articles that would summarize the requirements from relevant legal and regulatory documents and assess an actual compliance on the capital market in the Czech Republic are very limited. This paper should therefore contribute to filling 
the gap in studies aimed specifically to disclosures in the Czech Republic and its practical adoption by means of a content analysis, using a scoring system as described further in the paper.

\section{General Disclosure Obligation of Listed Companies in the Czech Republic}

Obligations related to providing external information of companies listed on the PSE differ from those imposed on ordinary businesses. For such companies both current and potential investors require objective and reasonably detailed information about the issuers of shares so that these investors could use them to make rational economic decisions. These obligations can be divided into two main categories according to their recurrence - to continuous and periodic ones.

Continuous obligation regarding information provided to the public requires to provide current data according to the Act no. 256/2004 Coll., On Capital Market Undertakings. Companies thus have to ensure that investors can base their economic decision-making in all relevant areas possible to the most recent information available. This information typically includes particular data on the company's financial position, its financial performance, valuation of its assets and other facts relevant to investors, as well as other stakeholders. All this data must be among other ${ }^{1}$ sent to the Czech National Bank (CNB), which subsequently publishes it on its website. The disclosure is, however, only required if the information has not already been publicly known.

In contrast, periodic information disclosure relates to an obligation to provide the public with information in predetermined time intervals (usually annually or semiannually), disclosing a broad portfolio of both up-to-date financial and nonfinancial information. These data are usually published in a form of standardized reports.

The most crucial of the periodic reporting obligations is undoubtedly the duty to regularly publish a report of the company's or the group's performance over the year. This should be fulfilled by means of a written report containing a set of mandatory information to be disclosed by all listed companies unconditionally. Such report is called the annual report, or the consolidated annual report ("AR"). The most important requirements for the content of ARs of listed companies in the Czech Republic are described in detail in next sections of this paper.

${ }^{1}$ For the other means of disclosure of accounting information required in the Czech Republic refer to Istvanfyova, Mejzlik, Pelak, 2010, p. $65-68$. 
Čevela, D.: $\quad$ Quality of Information Disclosed in Annual Reports of Listed Companies in the Czech Republic.

\section{Specific Requirements for Annual Reports of Listed Companies in the Czech Republic}

Preparation and publishing of an AR should be considered to be an essential periodic disclosure obligation of a listed company. However, it is necessary to note that currently not all the requirements are concentrated to a single legislative document, which would list them exhaustively. For a complete list of such requirements for the previous accounting period it is therefore necessary to follow the requirements arising in particular from the following documents:

- Act no. 256/2004 Coll., On Capital Market Undertakings, as amended (the "Act on Capital Market"),

- Act no. 563/1991 Coll., On Accounting, as amended (the "Act on Accounting") and

- Act no. 513/1991 Coll., Commercial Code, as amended (the "Commercial Code").

These acts however also refer to other related documents, among others for example to International Financial Reporting Standards (IFRS).

The above mentioned acts were fully valid only until 31 December 2013, i.e. for all ARs valid for an accounting period to that date. A major change for the next accounting period was an implementation of the new Act on Business Corporations, and indirectly also some new or modified IFRS standards, which became effective for accounting period ending after 1 January 2014.

It is necessary to emphasize the fact that the requirements given by the legislation cannot be understood as an exhaustive list and the primary aim which should be considered by any entity, is the need to truly and fairly state its current financial and non-financial data. This main objective is stated not only in the Act on Accounting as such, but is emphasized as well as the main criterion in the Act on Capital Market. This means that if there are other matters not considered directly in any of the relevant legislative document, these have to be disclosed as well their nature may significantly influence the economic decisions of its users. The emphasis on appropriate quality of information is also present in the Czech National Bank implementing decree no. 234/2009 Sb. on Protection against Market Abuse and Transparency. This defines the basic requirements for the quality of internal information disclosed by a listed company as follows:

- for the purpose of determining the requirements for quality of inside information the information is considered to be accurate if

- it contains a set of events and conditions that has occurred or which may reasonably be expected to occur in the future, and 
- the information is specific enough so that its user can reasonably conclude about the possible impact of circumstances or events on the price of the relevant financial instrument or instruments the value of which is derived from this financial instrument;

- the information that 'could after becoming publicly known significantly affect the price or a yield of a financial or derivative instrument,' is such information which may be assumed to be taken into account by a rational investor when making investment decisions.

These underlying requirements must therefore be taken into account when drawing an $\mathrm{AR}$ as a basic requirement for the truthfulness and fairness of the information presented.

\section{Methodology and Data}

Compliance with the applicable legislation is examined in this paper by means of a review of official ARs for the financial year ending in 2013, which companies have to disclose mandatorily through a central depository of the CNB. The analysis was performed on ARs of all listed companies shares of which were traded at least once during 2013. Banks were excluded from the sample of companies analysed, because the requirements imposed on these companies differ significantly from other listed companies and would require an establishment of different set of indicators, which would considerably reduce their comparability. For the similar reasons the issuers of bonds were not included either as far as only limited disclosures are required for such companies, which further vary based on the nominal value of the listed bonds. That made a total of 21 companies ARs that were analysed in this paper.

A compliance with the total of 40 individual requirements was analysed for all 21 companies (therefore there is a total of 840 observations). These are shown and described in more detail in Appendix 1. In addition to identifying the requirements the table also includes a brief description of how to meet these statutory requirements, i.e. what information (both quantitative and qualitative) should be included in the AR, so that their content and form will provide its users with easily accessible and interpretable information. The following classification of the requirements is not entirely arbitrary but respects the breakdown set by the guidance of the CNB for the content of ARs of listed companies, or other relevant legislation in place. All these requirements were assigned the same weight for the purpose of the final evaluation.

The output of the analysis is a quantitative matrix that assesses to what extent these companies met the analysed requirements. These were assigned a value of one (requirement fully met) or zero (requirement not fully met) points for each as 
Čevela, D.: $\quad$ Quality of Information Disclosed in Annual Reports of Listed Companies in the Czech Republic.

a dummy variable. There are no different values other than these e.g. for requirements met only partially. Compliance with the requirements was checked for all categories individually, but for the clarity it is shown in an aggregation per individual area i.e. namely per a) Financial statements b) Report on relations and the Report of the Board of Directors c) Notes and other information, and d) Financial position and financial results. The results are shown as a percentage rate depending on the number of requirements that were presented sufficiently in the analysed AR. Verbal evaluation is carried out within the next section. The conclusion then summarizes the key findings from this research.

\section{Results and Discussion}

Results of the empirical testing as per methodology described above is shown in the following table:

Tab. 1: Evaluation of the compliance with the requirements per individual company (in \%)

\begin{tabular}{|c|c|c|c|c|c|}
\hline $\begin{array}{l}\text { Company } \\
\text { Statutory auditor }\end{array}$ & $\begin{array}{l}\text { Financial } \\
\text { statements }\end{array}$ & $\begin{array}{l}\text { Report on } \\
\text { relations, } \\
\text { Report of the } \\
\text { Board }\end{array}$ & $\begin{array}{l}\text { Notes and } \\
\text { other } \\
\text { information }\end{array}$ & $\begin{array}{l}\text { Financial } \\
\text { position and } \\
\text { results }\end{array}$ & $\begin{array}{l}\text { Total } \\
\text { average }\end{array}$ \\
\hline $\begin{array}{l}\text { CETV } \\
\text { Deloitte LLP }\end{array}$ & 78 & 75 & 100 & 93 & 90 \\
\hline $\begin{array}{l}\text { CEZ } \\
\text { Ernst\&Young s.r.o }\end{array}$ & 100 & 100 & 100 & 100 & 100 \\
\hline $\begin{array}{l}\mathbf{E 4 U} \\
\text { BDO CB s.r.o. }\end{array}$ & 100 & 75 & 100 & 100 & 98 \\
\hline $\begin{array}{l}\text { Energoaqa } \\
\text { Eleni Lipperova }\end{array}$ & 100 & 100 & 50 & 80 & 87 \\
\hline $\begin{array}{l}\text { Energochemica } \\
\text { Mazars Audit s.r.o. }\end{array}$ & 100 & 100 & 100 & 100 & 100 \\
\hline $\begin{array}{l}\text { Fortuna } \\
\text { Ernst\&Young LLP }\end{array}$ & 89 & 75 & 100 & 100 & 95 \\
\hline $\begin{array}{l}\text { Jachymov PM } \\
\text { Mazars Audit s.r.o. }\end{array}$ & 100 & 100 & 100 & 100 & 100 \\
\hline $\begin{array}{l}\text { NWR } \\
\text { KPMG Audit PLC }\end{array}$ & 89 & 100 & 100 & 93 & 95 \\
\hline $\begin{array}{l}\text { ORCO } \\
\text { KPMG Luxemburg }\end{array}$ & 100 & 75 & 100 & 93 & 95 \\
\hline $\begin{array}{l}\text { Pegas } \\
\text { Deloitte Audit }\end{array}$ & 100 & 75 & 100 & 100 & 98 \\
\hline $\begin{array}{l}\text { Philip Morris } \\
\text { PwC Audit s.r.o. }\end{array}$ & 100 & 100 & 100 & 100 & 100 \\
\hline
\end{tabular}




\begin{tabular}{|c|c|c|c|c|c|}
\hline $\begin{array}{l}\text { Company } \\
\text { Statutory auditor }\end{array}$ & $\begin{array}{l}\text { Financial } \\
\text { statements }\end{array}$ & $\begin{array}{l}\text { Report on } \\
\text { relations, } \\
\text { Report of } \\
\text { the Board }\end{array}$ & $\begin{array}{l}\text { Notes and } \\
\text { other } \\
\text { information }\end{array}$ & $\begin{array}{l}\text { Financial } \\
\text { position and } \\
\text { results }\end{array}$ & $\begin{array}{l}\text { Total } \\
\text { average }\end{array}$ \\
\hline $\begin{array}{l}\text { Prazske sluzby } \\
\text { BDO Audit s.r.o. }\end{array}$ & 100 & 100 & 100 & 100 & 100 \\
\hline $\begin{array}{l}\text { RMS Mezzanine } \\
\text { KPMG Audit s.r.o. }\end{array}$ & 100 & 100 & 100 & 100 & 100 \\
\hline $\begin{array}{l}\text { Stock } \\
\text { Ernst\&Young LLP }\end{array}$ & 100 & 50 & 100 & 86 & 90 \\
\hline $\begin{array}{l}\mathbf{O 2} \\
\text { Ernst\&Young s.r.o. }\end{array}$ & 100 & 100 & 100 & 93 & 98 \\
\hline $\begin{array}{l}\text { TMR } \\
\text { KPMG Slovensko }\end{array}$ & 100 & 75 & 100 & 86 & 93 \\
\hline $\begin{array}{l}\text { Toma } \\
\text { NEXIA AP a.s. }\end{array}$ & 100 & 100 & 100 & 100 & 100 \\
\hline $\begin{array}{l}\text { Unipetrol } \\
\text { KPMG Audit s.r.o. }\end{array}$ & 100 & 100 & 100 & 100 & 100 \\
\hline $\begin{array}{l}\text { Vet Assets } \\
\text { SPICA Audit s.r.o. }\end{array}$ & 100 & 100 & 100 & 100 & 100 \\
\hline $\begin{array}{l}\text { VGP } \\
\text { Deloitte BV o.v.v.e }\end{array}$ & 89 & 75 & 100 & 80 & 87 \\
\hline $\begin{array}{l}\text { VIG } \\
\text { KPMG Austria AG }\end{array}$ & 89 & 75 & 100 & 86 & 90 \\
\hline Average & 97 & 92 & 98 & 95 & \\
\hline
\end{tabular}

Source: authorial qualitative research.

Based on the analysis of ARs published by the listed companies using the CNB database we can conclude that companies inform their stakeholders well and in material aspects meet the regulatory requirements. Most of the identified mistakes are rather formal in nature, and cannot cause significant information deficit. Specifically, the following deficiencies were identified (shown in descending order per area analysed):

\subsection{Financial Statements}

There was no AR identified that would not include both individual and consolidated financial statements (if applicable) prepared in accordance with IAS/IFRS. All analysed AR contained the so-called complete set of financial statements, i.e. a statement of financial position, statement of profit or loss and other comprehensive income, statement of changes in equity, statement of cash flows and explanatory notes. 
Čevela, D.: $\quad$ Quality of Information Disclosed in Annual Reports of Listed Companies in the Czech Republic.

All companies published their AR with the auditor's reports attached. These reports were in all instances either unqualified, or in some cases unqualified with an emphasis of matter. However, ARs of CME, Fortuna, NWR and VGP (in all cases these AR were audited by foreign external auditors), contained statements which were not signed by the statutory auditor (i.e. it contained only the transcript of the report). Companies ordinarily fulfilled this requirement by attaching scanned (signed) original version of the audit report (none of them was published with an electronic signature). This approach may therefore rise some doubts about whether the accompanying auditor's report actually is the final and approved version of this report.

Finally, it should be noted, that the AR of CETV was prepared primarily in accordance with US GAAP, and thus logically did not meet the requirement for the declaration of full and unconditional compliance with IFRS. However, it was still evaluated for compliance with all the other requirements.

\subsection{Report on Relations and the Report of the Board of Directors}

Based on the analysis performed all companies submitted sufficient information required by laws and regulations relevant to the Report on relations between related parties (according to Section 66 of the Commercial Code) and Report of the Board of Directors (according to $\S 192$ of the Commercial Code). Companies CETV, E4U, Fortuna, ORCO, Pegas, Stock, TMR, VGP and VIG, however, did not present the Report on relations in a separate section of the AR, but as an integral part of this report instead and sometimes even at various places within the text. Such approach may in some cases make it more difficult for the stakeholders to access the required information, and also in most cases makes it virtually impossible to assess whether the mandatory requirement to process such information within three months after the reporting period was met.

\subsection{Notes and Other Information}

Listed companies are required to indicate within the notes to AR various information related mainly to internal processes (e.g. internal control system, decision-making process of the General Meeting and Supervisory Board, Corporate Governance Code, etc.), the managing directors (income, remuneration policy et al.) and securities issued. Based on the analysis performed the companies published all relevant information in a good quality, although there may be some objections to their formal presentation. Another objection is to AR of CETV that published a version not signed by the statutory body, therefore it is not quite clear whether it is the most current and approved version of the document. On the other hand, Energoaqua failed to include information about managing directors, audit fee paid for the statutory audit services, a description of the functionality of the 
internal control system and the corporate governance codes which the company follows, making it the least rated AR in terms of quality of information provided.

However, this was an area in which the companies were generally able to sufficiently meet most of the criteria and in any other AR there were no missing or insufficiently described information found.

\subsection{Financial Position and Financial Results}

This area covers a relatively broad portfolio of information especially of operational and economic nature, which should provide its users with sufficient information for the purposes of assessing the historical performance of the company. Companies were able to meet these requirements in all the most significant aspects. It is noteworthy that companies explicitly reported if a requirement was not relevant for them (e.g. did not provide a description of fixed assets if they did not own any, informed that there are not any contracts not concluded at arm's length terms etc.), rather than just simply neglect such area.

On the other hand, there were some minor deficiencies, when some additional information particularly in relation to managing directors were omitted. ARs of CETV, Energoaqua, Fortuna, NWR, ORCO, Stock, O2, TMR, VGP and VIG did not include an information whether or not the managing directors were convicted of criminal offenses in the period of last five years. CETV, NWR, Stock, O2, TMR and VGP also did not include detailed information on material litigations and claims with possible future negative impacts on the company or an absence of such disputes.

\subsection{Other Findings}

Generally, we can conclude that if you trust the judgment of statutory auditors and data contained in the ARs are in all material aspects disclosed truly and fairly, economic decisions made on the basis of such information should not be materially affected. However, there still are several negative factors that affect the traceability of the published data.

One of them is undoubtedly the form in which companies fulfil their obligations. The information presented in the form of simple tables are in fact much more user friendly and easier to identify than the same information presented within a seamless block of text along with other data. Due to a considerable extent of submitted ARs (which normally contain 120-150 pages of information and graphics) this information may be overlooked or misinterpreted even with one's careful effort to familiarize in detail with the content of the document.

A choice of the language for textual information can also become an obvious inhibitory factor. An option to publish AR either only in English or Czech without 
Čevela, D.: $\quad$ Quality of Information Disclosed in Annual Reports of Listed Companies in the Czech Republic.

translation to the other language is an obvious reduction in the administrative burden on reporting entities. It is however also possible that this may become a natural obstacle in the struggle to fulfil the information needs especially of the smaller investors, which can have problems to understand the foreign text which is full of technical jargon. Most convenient would therefore be to have an easy access to a bilingual version of the AR published rather than to an official Czech or English version only.

\section{Conclusion}

For a quality investor decision-making it is essential that they have all the sufficient, appropriate and materially correct information. A significant portion of such investor information is obtained through the annual reports of the listed companies, by which they fulfil their disclosure obligations set by the applicable law.

The objective of this research was to identify the information disclosure requirements currently imposed on companies in the Czech Republic and evaluate the level to which they are met by companies listed on the Prague Stock Exchange. Based on the analysis, we can conclude that:

- Despite the fact that this area is regulated by several laws and regulations the companies in material aspects fulfil their information obligation towards the potential investors and other users of the financial and non-financial information;

- Identified deficiencies are usually rather more formal than factual in nature;

- We observe that if some deficiencies occur, they are mostly found in annual reports of foreign companies or companies audited by a foreign statutory auditor respectively;

- Companies in average were very successful in disclosing information required for financial statements and explanatory notes, in line with the Act on Accounting and the Act on Capital market;

- In average the least satisfactory was the compliance with the Commercial Code regarding the disclosure of Report on relations and the Report of the Board of Directors.

Based on the research all the companies analysed performed well in meeting the requirements given by the legislation as far as the lowest average score achieved was $87 \%$ (by companies Energoaqua and VGP).

The findings identified are consistent with other researches that suggest that despite a defined set of disclosure obligations exist the companies tend to be rather 
inconsistent in the way they comply with them (Daske et al., 2013, Verriest et. al., 2013).

However, this study shows a high level of compliance of companies listed on PSE that supports a notion that the disclosure quality can be strongly influenced by country-specific and local factors (Akman 2011, Glaum \& Street, 2003, Glaum et al., 2013, Miková 2014).

An interesting subject for a further analysis in this area could be to extend an interval for examining the quality of the information provided and compliance with legislation for the subsequent periods. Especially in connection with the adoption of the new Act on Business Corporations and the updated Act on Capital Market valid from 2014 and to perform the analysis over a longer time series to evaluate the development of the level of compliance over time. If the dataset would be large enough statistical methods could be used to evaluate the result and find some patterns and correlation with other variables (such as company size, its performance, statutory auditor etc.).

The analysis could also be performed by a wider panel of researchers to determine, whether and to what extent can evaluators differ in their assessment of compliance with individual requirements based on their individual judgment and perception.

\section{References}

Act no. 256/2004 Coll., On Capital Market, as amended. Available from: <http://www.podnikatel.cz/zakony/zakon-c-256-2004-sb-o-podnikani-nakapitalovem-trhu/zneni-20130630/uplne/>. [13 October 2014].

Act no. 513/1991 Coll., The Commercial Code. Available from: <http://business.center.cz/business/pravo /zakony/obchzak/>. [13 October 2014].

Act no. 563/1991 Coll., On Accounting. Available from: <http://www.zakonyprolidi.cz/cs/1991-563>. [13 October 2014].

Akman, N. H., 2011. The Effect of IFRS Adoption on Financial Disclosure: Does Culture Still Play a Role? American International Journal of Contemporary Research 1, 7-17.

CNB - Central storage of regulated information (annual reports of all companies). Available from: <https://oam.cnb.cz/sipresextdad/SIPRESWEB.WEB21. START_INPUT_OAM?p_lang=cz>. [28 October 2014].

CNB - contain particulars of the annual report and consolidated annual report. Available from: <http://www.cnb.cz/miranda2/export/sites/www.cnb.cz/ cs/dohled_financni_trh>. [13 October 2014]. 
Čevela, D.: $\quad$ Quality of Information Disclosed in Annual Reports of Listed Companies in the Czech Republic.

Daske, H., Hail, L., Leuz, C., Verdi, R. 2013. Adopting a Label: Heterogeneity in the Economic Consequences Around IAS/IFRS Adoptions. Journal of Accounting Research 3, 495-547.

Decree no. 234/2009 Sb. protecting against market abuse and transparency. Available from: <https://www.cnb.cz/miranda2/export/sites/www.cnb.cz/cs/ legislativa/leg_kapitalovy_trh/vyhlasky/download/vyhlaska_234_2009.pdf>. [13 October 2014].

Dyczkowska, J., 2014. Assessment of quality of internet financial disclosures using a scoring system. A case of Polish stock issuers. Accounting and Management Information Systems 1, 50-81.

Glaum, M., Schmidt, P., Street, D. L., Vogel, S., 2013. Compliance with IFRS 3 and IAS36 - required disclosures across 17 European countries. Accounting and Business Research 3, 163-204.

Glaum, M., Street, D. L., 2003. Compliance with the Disclosure Requirements of Germany's New Market. Journal of International Financial Management and Accounting 1, 64-100.

Goodwin, J., Ahmed, K., Heaney, R., 2009. Corporate Governance and the Prediction of the Impact of AIFRS Adoption. ABACUS 1, 124-145.

Husták, Z., Šovar, J., Franěk, M., Smutný, A., Cetlová, K., Doležalová, D., 2012. Zákon o podnikání na kapitálovém trhu. Komentár. Praha, C. H. Beck.

IAS 1 - International Accounting Standard 1 - Presentation of Financial Statements. Available from: <http://eur-lex.europa.eu/LexUriServ/LexUriServ. do?uri=CONSLEG:2008R1126:20120609:CS:PDF>. [1 November 2014].

IAS 7 - International Accounting Standard 7 - Statement of Cash Flows. Available from: <http://eur-lex.europa.eu/LexUriServ/LexUriServ.do?uri=CONSLEG :2008R1126:20120609:CS:PDF>. [1 November 2014],

Istvanfyova, J., Mejzlik, L., Pelak, J., 2010. Progression of Financial Reporting in Czech Republic and its Regulation. European Financial and Accounting Journal 1, 64-77.

Prague Stock Exchange, Inc. Available from: <http://www.bcpp.cz/>. [13 October 2014].

Miková, T., 2014. Influence of IFRS on Earnings Manipulation: Evidence from the European Union. Acta Oeconomica Pragensia 6, 3-18.

Morais, A. I., Curto, J. D., 2009. Mandatory Adoption of IASB Standards: Value Revelenace and Country-Specific Factors. Australian Accounting Review 2, 128143.

Švestka, J., Spáčil, J., Škárová, M., Hulmák, M. et al., 2008. Občanský zákoník I. $\S 1-\S 459$. Komentáŕ. Praha, C. H. Beck. 
Verriest, A., Gaeremynck, A., Thorton, D. B., 2013. The Impact of Corporate Governance on IFRS Adoption Choices. European Accounting Review 1, 39-77. Zelenka, V., Zelenková, M., 2011. Konsolidační celek dle IFRS. Výklad. Finanční management \& controlling v praxi $6,36-41$. 


\section{Appendix 1: List of Requirements for Assessment Purposes}

\section{Requirements on ARs of listed companies per individual area}

\section{Requirement Expected compliance with the requirement}

\section{a) Financial Statements}

\begin{tabular}{ll}
\hline $\begin{array}{l}\text { Statement of financial } \\
\text { position }\end{array}$ & The statement of financial position in accordance with IAS. \\
\hline $\begin{array}{l}\text { Statement of profit or } \\
\text { loss and other } \\
\text { comprehensive } \\
\text { income }\end{array}$ & $\begin{array}{l}\text { The statement of profit or loss and other comprehensive income (or separate } \\
\text { statement profit or loss and a statement of comprehensive income) in } \\
\text { accordance with IAS. }\end{array}$ \\
\hline $\begin{array}{l}\text { Statement of cash } \\
\text { flows }\end{array}$ & The statement of cash flows in accordance with IAS. \\
\hline $\begin{array}{l}\text { Statement of changes } \\
\text { in equity }\end{array}$ & The statement of changes in equity in accordance with IAS. \\
\hline $\begin{array}{l}\text { Declaration of } \\
\text { compliance }\end{array}$ & $\begin{array}{l}\text { Explicit and unreserved statement of compliance with the applicable IFRS } \\
\text { (entity cannot declare only partial or limited compliance with IFRS). }\end{array}$ \\
\hline $\begin{array}{l}\text { Length of the } \\
\text { reporting period }\end{array}$ & $\begin{array}{l}\text { The length of the reporting period is at least one year (i.e. 52 weeks). If } \\
\text { there is a change in the accounting period, the entity has to disclose the } \\
\text { reason for this change and information that the amounts for the prior periods } \\
\text { are not entirely comparable. }\end{array}$ \\
\hline $\begin{array}{l}\text { Information about the } \\
\text { prior period }\end{array}$ & $\begin{array}{l}\text { Financial information for prior periods are presented both in the financial } \\
\text { statements and in the notes. }\end{array}$ \\
\hline $\begin{array}{l}\text { Identification of } \\
\text { financial statements }\end{array}$ & $\begin{array}{l}\text { The entity states whether the statements are individual or consolidated, } \\
\text { indicates the reporting currency, the level of rounding and reporting period. }\end{array}$ \\
\hline Auditor's report & $\begin{array}{l}\text { The auditor's report on the financial statements and ARs were published in } \\
\text { full, no parts of the report have been omitted. }\end{array}$ \\
\hline
\end{tabular}

b) Report on relations and the Report of the Board of Directors

The report on relations between related parties was prepared by the

Timely preparation statutory body in writing within max. three months after the reporting period.

Information on List of contracts concluded during the accounting period between related contracts concluded parties, including their description.

Other legal acts made

in the interest of related parties

List of unilateral or multilateral related party transactions, including the description of the considerations provided (supplies, works, services etc.).

Report of the Board of The Board will evaluate the company's business activities, risk, assets and Directors 
European Financial and Accounting Journal, year, vol.11, no. 2, pp. 21-36.

c) Notes and other information

\begin{tabular}{|c|c|}
\hline $\begin{array}{l}\text { Rights and obligations } \\
\text { associated with issued }\end{array}$ & $\begin{array}{l}\text { Description of obligations and rights arising from the possession of the } \\
\text { shares issued. }\end{array}$ \\
\hline $\begin{array}{l}\text { Directors' income, } \\
\text { shares held }\end{array}$ & $\begin{array}{l}\text { Description of both cash and non-cash income, at least separately for a) } \\
\text { members of statutory bodies b) members of the supervisory board c) other } \\
\text { persons with executive powers. Description of the shares, options and other } \\
\text { similar investment instruments in direct or indirect possession of such } \\
\text { persons. }\end{array}$ \\
\hline Directors' emolument & $\begin{array}{l}\text { Information about managing directors, including their names, their } \\
\text { functions and activities and principles of their remuneration. }\end{array}$ \\
\hline $\begin{array}{l}\text { Declaration of the } \\
\text { management }\end{array}$ & $\begin{array}{l}\text { Managers' statements that the annual report gives a true and fair view of the } \\
\text { financial position, business and the financial results of the listed company } \\
\text { and its group for the previous fiscal year and the future outlook for its } \\
\text { financial situation, business activities and financial performance. }\end{array}$ \\
\hline $\begin{array}{l}\text { Statutory auditor } \\
\text { remuneration }\end{array}$ & $\begin{array}{l}\text { Information on financial remuneration of auditors for statutory audit } \\
\text { services, for other assurance services, tax advisory services and other non- } \\
\text { audit services provided by auditors. }\end{array}$ \\
\hline $\begin{array}{l}\text { Internal control } \\
\text { system }\end{array}$ & $\begin{array}{l}\text { Description of the functionality of the internal control system and the } \\
\text { approach to risks associated with financial reporting process. }\end{array}$ \\
\hline $\begin{array}{l}\text { Statutory } \\
\text { representatives }\end{array}$ & $\begin{array}{l}\text { Description of the decision-making process and the composition of the } \\
\text { statutory body, supervisory board or other executive or supervisory bodies } \\
\text { and their committees. }\end{array}$ \\
\hline $\begin{array}{l}\text { Meeting of } \\
\text { shareholders }\end{array}$ & $\begin{array}{l}\text { Description of the decision-making process of the Shareholders' Meeting or } \\
\text { a similar meeting of owners. }\end{array}$ \\
\hline $\begin{array}{l}\text { Corporate governance } \\
\text { codes }\end{array}$ & $\begin{array}{l}\text { Information on the corporate governance codes that are either binding to } \\
\text { the entity or adopted voluntarily and a note if the company does not comply } \\
\text { with some part of the Code and the reason and justification for the non- } \\
\text { compliance. }\end{array}$ \\
\hline Equity structure & $\begin{array}{l}\text { Detail structure of the equity, incl. securities not-admitted to trading and } \\
\text { listing of all types of shares issued including their proportion on the total } \\
\text { equity. }\end{array}$ \\
\hline $\begin{array}{l}\text { Other information on } \\
\text { issued shares }\end{array}$ & $\begin{array}{l}\text { The listed company gives information about the limitations and restrictions } \\
\text { on the transferability of shares, voting rights and special rules for the } \\
\text { election and dismissal of the statutory body, or change of the articles of } \\
\text { incorporation. }\end{array}$ \\
\hline Employee shares & $\begin{array}{l}\text { Information on programs on the basis of which employees and statutory } \\
\text { representatives can acquire shares and other securities, or options for such } \\
\text { securities. }\end{array}$ \\
\hline
\end{tabular}


Čevela, D.: $\quad$ Quality of Information Disclosed in Annual Reports of Listed Companies in the Czech Republic.

\section{d) Financial position and financial results}

\begin{tabular}{|c|c|}
\hline $\begin{array}{l}\text { Basic information } \\
\text { about the company }\end{array}$ & $\begin{array}{l}\text { The company should indicate its business name, address and identification } \\
\text { number, place of registration and the registration number, date of } \\
\text { incorporation and important events in the development of the main business } \\
\text { activities. }\end{array}$ \\
\hline Jurisdiction & Information about the legal form of the entity and the applicable law. \\
\hline Business overview & $\begin{array}{l}\text { Description of the main business activities of the company, product } \\
\text { (services) portfolio, a description of the markets in which the company } \\
\text { operates and allocation of revenues to these markets. }\end{array}$ \\
\hline $\begin{array}{l}\text { Property, plant } \\
\text { and equipment }\end{array}$ & $\begin{array}{l}\text { Description of both already purchased and planned significant tangible } \\
\text { fixed assets and its easements. Issues that may affect the utilization of these } \\
\text { assets should be disclosed as well. }\end{array}$ \\
\hline $\begin{array}{l}\text { Operational and } \\
\text { financial overview }\end{array}$ & $\begin{array}{l}\text { Development of the financial situation for the current fiscal period, factors } \\
\text { significantly affecting the operating income and change in the company's } \\
\text { turnover. }\end{array}$ \\
\hline
\end{tabular}

Sources of capital financing and restrictions on the use of capital resources. Includes a short analysis of cash flows.

Members of the administrative, management and supervisory bodies and senior management Significant main activities of these persons outside the company, and information about possible conflicts of interest. The term of office, information on contracts for benefits after termination of employment, professional skills, membership in other administrative / managerial / supervisory bodies of such persons and any convictions for fraudulent offenses, bankruptcy and liquidation for a period of five years.

Number of employees and, if possible, its breakdown by category (of

Employees activity) and geographic location. A description of the participation of employees in the listed company's equity.

Main shareholders Identification of persons with direct or indirect participation in the capital of the company or voting rights and the amount of such shares.

Dividend policy Dividend policy and dividend per share paid in the current financial period.

Litigations and claims Legal proceedings which had or might have a significant impact on the financial position and/or profitability of the company.

Shareholders' capital Indication of the number of issued, subscribed and outstanding shares, their description and number of shares held by the company or its subsidiaries.

Summary of major contracts, other than contracts concluded under arm's

Significant contracts length terms, entered into by the listed company or any other member of the group of companies.

Subsidiaries Information about the legal entities in which the company holds shares on their capital with significant influence.

Regulated markets

Names of the regulated markets (domestic and foreign), on which the listed company's securities are admitted for trading, including the date from which they are traded on these markets.

Source: Obsahové náležitosti výroční zprávy a konsolidované výroční zprávy emitenta kótovaného cenného papíru za rok 2013, Available from: <http://www.cnb.cz/cs/ dohled_financni_trh/vykon_dohledu>; authorial settle and commentary. 